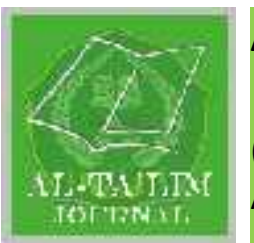

AL-TA'LIM JOURNAL, 23 (2), 2016, (114-127)

(Print ISSN 1410-7546 Online ISSN 2355-7893)

Available online at http://journal.tarbiyahiainib.ac.id/index.php/attalim

\title{
Islamic Pre-School Management and Its Implications towards Students' Learning Quality Improvement
}

Received: 19 ${ }^{\text {th }}$ January 2016; Revised: $16^{\text {th }}$ February 2016; Accepted: $19^{\text {th }}$ July 2016

Permalink/DOI: http://dx.doi.org/10.15548/jt.v23i2.169

\section{Rosniati Hakim}

Institut Agama Islam Negeri Imam Bonjol

Padang, West Sumatra, Indonesia

Email: rosniati_hakim@yahoo.com

\begin{abstract}
Islamic education in schools had not completely assessed the development of students' character and personality. Therefore, additional religious education through non-formal education and religious practices were needed in Islamic PreSchools. It provided a forum to foster, develop, cultivate, and transform the religious value of the students to improve their personality. The purpose of this research was to examine social phenomenon that occur naturally through the facts related to management activities of students. Qualitative research was used in this study where the data taken from head of Islamic preschool and the school deputy, teacher, staffs, mosque administrators of Baitul Haadi, administrator of the school, staffs of Ministry of Religious Affairs as well as Islamic pre-school inspectors, parents, community leaders, and administrators of professional organizations. The finding showed that students' management applied in Islamic pre-school through the management functions is able to provide the successful of student's education and learning implementation. It was also found that student management applied in Islamic pre-school is planning activities of students' admission process through the administration regularly with various regulations related to the success of education. Thus, it is expected that the government will provide the guidance and implement constant supervision in accordance with applicable regulations.
\end{abstract}

Keywords: Student management, Islamic pre-school education, the quality of learning.

How to Cite: Hakim, R. (2016). Islamic pre-school management and its implications towards students' learning quality improvement. Al-Ta Lim Journal, 23(2). doi:http://dx.doi.org/10.15548/it.v23i2.169

\section{INTRODUCTION}

Learners are society members attempting to develop their potential through a learning process that is available on the type and level of education (Act 20 of 2003, article 1, paragraph 4). Education prepare new generation of the nation's since childhood through a variety of educational institutions. Children' education in the field of science and technology need to be balanced with religious education by means to control and inherit good moral into their life. So what worries could be anticipated early? (See: QS. al-Nisa; 4: 9 and al-Munafiqun; 63: 9).

The development of human balance, vigorous and strong personality is totally influenced by religious education and internalization of religious values. Islamic 
pre-school is a process or stage of personality building of a generation. Islamic teaching and education historically arise naturally through peaceful acculturation according to the needs of society. There are variety of Islamic schools in every remote village which are different from one region to other, such as mosque lecture, public hall lecture, religious schools and others (Mustafa \& Aly, 1999). It seemed that the Islamic community needs additional education and teaching of Islam for their children. In West Sumatra it is known as recitation of the Qur'an and the book (al kitab). It is also known as Surau education system. The 20th century generation managed many leaders, scholars / professors in the field of Islamic Studies, independent figures and educational institutions, known as Madrasah (Safwan \& Kutoyo, 1980).

Government programs supported the development of the faith and piety of the generations. The existence of legislation and government regulation presents new chapter for the world of religion and religious education in Indonesia such as Law No. 20 of 2003 Article 12 paragraphs 1, 2 and 3. No 55 of 2007 (Ministry of Religious affairs no. 3, 2012, no. 13, 2014). Padang Local Regulation No. 06, 2003, Governor Regulation no 70, 2010. It means that the State / government apprehend the diversity of models and forms of education in Indonesia. The existence of these regulations has become a "crutch" for Islamic school experiencing an identity crisis. IPS is the Islamic religious educational institution organized as a accompaniment to the implementation of Islamic religious education in basic education in support of long life education (Mubarok, 2000).

Learners must be prepared as well as possible both social-institution and functional academic. It should initiate from the lowest level of education (Azizy, 2003). Islamic concept preaches proactive and reactive action (amar ma'ruf nahi mungkar) to the surrounding environment. This initiate that the education is the responsibility of society, family, institution, government, social environment, etc. (See: Q.S. Ali Imran, 3: 104).

The existence of Islamic pre-school is indispensable because people consider that the religious education in school is inadequate in term of learning duration. Parents have high demand for development of religious life and the development of good moral for their children. Parents fear against the increasing degeneration among school-age children. According to the ability to understand and read the Quran as the basic lesson in Baitul Haadi became a core expectation for the community as well as the past. But the ability and attitude degradation of learners reflects the expected goals. Thus, this should be the focus.

Islamic education in Indonesia according to Rahim (2001) is a legacy of civilization, and as an asset of national education development. The success of the students realizes its goals and functions. It requires good institution management, and support of various elements. The quality of leadership determines the success of students in Madrasah. While the failure and success is determined by the headmaster/ leaders (Mulyasa, 2004).

Comprehensive management should be directed to various aspects or functions initiated from planning, implementation and supervision, starting from input, process, output, and outcome of Madrasah h management. How was the implementation of student management of Baitul Haadi in leading success? Islamic Pre-School management is managed simply. The ability of professional teachers in their field has not been totally as expected. Some people argue that teaching in Islamic pre-school is a stopover for teachers to acquire new career or the place for apprentice to accomplish his profession. It seems that teaching in this school is not professional. Religion ministry 
guidance and supervision is not maximal yet as well as the potential of Islamic pre-school is still very varied. These phenomena will influence the objective of Islamic pre-school. To overcome these problems, Islamic preschool should be administered professionally with appropriate student management to gain demand objective. Student management of Islamic pre-school Baitul Haadi Padang has provided alternative solutions to meet these demands by implementing various student management activities.

\section{METHOD}

This research was conducted at Islamic pre-school Baitul Haadi Padang. The simplicity of this social situation was as determination of this research place. This situation was easy to observe, practicable, controllable, accessible, and essential to observe (Muhadjir \& others, 1996; Nasution, 1992). This Islamic pre-school was located in Aur Duri Indah Complex VI Parak Gandang Timur Padang, West Sumatra. It covered the area of $2700 \mathrm{Ms}$. Besides, in this district there were also 8 other Islamic pre-school. The deciding of this school was intended for a specific purpose that is to learn from the student management experience conducted by the head of the school of Baitul Haadi. This school provides Islamic religious education for children of primary school age. It achieved public interest and appointed as sequential Islamic pre-school because of good management as well as achievements obtained.

Research data source using purposive sampling technique was to determine the sample with a specific purpose to provide data (Arikunto, 2010). The criteria of informant selection were honesty, communication ability, group member, and has a particular view about something or about events that happened. Those Research subjects were head of Islamic pre-school and the school deputy, teacher, administration/ coordinator staffs, mosque administrators of Baitul Haadi, administrator of the school, staffs of Ministry of Religious Affairs as well as Islamic pre- school inspectors, parents, community leaders, and administrators of professional organizations. Written sources are books, documents, archives, the data of teachers and learners, monthly and annual reports, and statistical data. Other supporting data such as photographs and recording data described the atmosphere naturally.

Duta Collection $\longrightarrow$ Field Noli: $\longrightarrow$ Deitription

The characteristics of the qualitative research was data and information gathered through physical and psychological approach of the phenomenon studied, words form rather than numbers in order to understand the meaning of the actions of the informants through words, experience and skills supported by physical evidence. All the information of phenomenon was arranged in verbal description. Data collection in qualitative research was accomplished through participant observation, in-depth interviews, and documentation (Muhadjir \& others, 1996). The process of field notes was as follows:

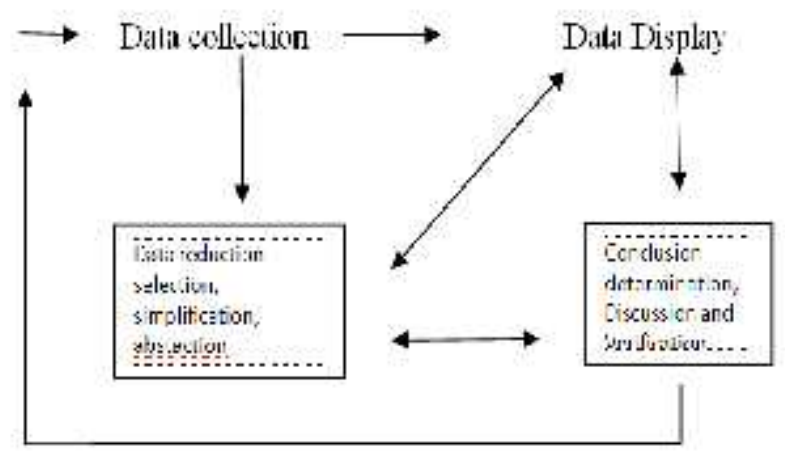

Figure 1. Diagram of Data Analysis of Interactive Model

\section{Test of Validity}

The steps to attain the level of outcome validity of qualitative research were carried out through four kinds of criteria or requirements. First, credibility (reliability), transferability (transferable), dependability (reliable), and conformability (confirmed). 


\section{RESULT AND DISCUSSION \\ Islamic Pre-School Students' Management}

Student management is a process of activity setting related to learners in achieving educational objectives. The whole educational program of Islamic pre-school is geared towards the development of self-learners, better knowledge, attitudes and skills. To find out how student management applied in Baitul Haadi can be observed through the following activities:

Table 1. Student Management Applied in Baitul Haadi Islamic Pre-School

\begin{tabular}{|c|c|c|}
\hline No & Management Activity & Activity \\
\hline \multirow[t]{8}{*}{1} & Planning and & 1. New student enrollment preparation \\
\hline & Students' Data & 2. School capacity determining, / stipulation analysisi \\
\hline & Collection & 3. Requirement determining \\
\hline & & 4. Enrollment committee determining \\
\hline & & 5. Role and Method \\
\hline & & 6. orientation \\
\hline & & 7. Student Data Collection and Registration \\
\hline & & 8. Regulation and Student Attendance List . \\
\hline \multirow[t]{6}{*}{2} & Students' Organize & 1. Class Grouping \\
\hline & And Placement & 2. Classroom Organization Grouping \\
\hline & & 3. Certain Program and model Grouping \\
\hline & & 4. Task Grouping \\
\hline & & 5. Interest and Skill Grouping \\
\hline & & 6. Early Morning Learning Grouping \\
\hline \multirow[t]{6}{*}{3} & Students' Guidance & 1. Through Activities and Extracurricular \\
\hline & & 2. Through Student's Organization \\
\hline & & 3. Through Early Morning Learning \\
\hline & & 4. Through Graduation Ceremony and Khatam Al qur'an \\
\hline & & 5. Through student's Disclipine \\
\hline & & 6. Through Student Orientation \\
\hline \multirow[t]{10}{*}{4} & Students' supervision and & 1. Student Supervision \\
\hline & assessment. & 2. Classrom vacation \\
\hline & & 3. Student Progress Assessment \\
\hline & & 4. Reward Endue \\
\hline & & 5. Attendance and Administration Control \\
\hline & & 6. Observe and Recommend Student Tranfer \\
\hline & & 7. Supervise Student's Progress and Graduation \\
\hline & & 8. Supervise Student Extrication \\
\hline & & 9. Monitoring and Direct Student Activity Assessment \\
\hline & & 10. Written and Spoken Report Analysis \\
\hline
\end{tabular}

Islamic pre-school plans and prepares for establishment of madrasah capacity, the determination of students prospective, and new student admissions committee. But, in general, Islamic pre-school is different from other schools in term of student's registration.
Registration is started from early of June. From the writer observation, not all Islamic pre-schools apply this management.

It is known that the planning of students is designed and implemented with 
structured cooperation and complete responsibility. Thus, Islamic pre-school becomes alternative for parents and society either in Aur Duri Indah society or in other society. All elements involved students in order to create proper learning activities. Compiled Planning leads Islamic pre-school to the development of high-quality educational implementation as expected.

Organizing is the process of grouping all the assignments, responsibilities, authority and components in the process of cooperation. Thus, it enables to emerge a good working system in order to achieve the goal. Organizing or student placement conducted in various forms as described. Through these groupings, there are a variety of division tasks, scheduled, by empowering the students. Teacher only acts as supervisor, monitor, guider, director, and leader. This is implemented with sincerity and responsibility by each teacher. Nurtured students are able to organize themselves, friends, their senior or junior).

Learners are grouped into several sections according to the task. In pre-class, students are supervised for less than a year expected to be able to read basic of The Quran, memorize the prayers and read of some The Quran letters corresponding to Islamic pre-school program. Before they were placed into upper grade, their abilities were commemorated in the iqra' graduation ceremony. This is the main program of Islamic pre-school Baitul Haadi because within 6 to 10 months, the Islamic pre-school is able to attain the objective. There are a variety of tasks in this grouping empowering the students. Tasks implementation is wellcoordinated to regulate accurately the process of implementation.

Students' development was an activity directing students to grow and develop according to the capacity and interest, as well as being a social skilled and individual. Student development is done through variety of skills, attitudes, and the formation of personality, through a learning process inside and outside of the classroom. Student competitions will enhance student capability and stimulate student interest.

Student developments in various activities were as follow:

a. Intra-curricular and extra-curricular through the management of classroom activities, pre-learning activities, reading The Quran activities, education activities at dawn, art activities and other supporting activities by teacher supervision. This program empowers students through continuously activities and responsibilities in order to become a habit in student's life.

b. Through student's organizations such as line-up activity and afternoon learning program as well as educational dawn activities. Such activities go according to predefined rules. Students who are in regular duty will fulfill the rules as a leader and regulator of the implementation of these activities. Everything goes regularly. This activity is defined as students exercise to be able to educate them and train their leadership ability. This activity can be completed continuously under teacher's supervision.

c. Through Dawn educational activity except the role of the leader of prayer (imam) and additional education lessons in dawn program. Student attitude and performance is well educated in dawn education program. This program includes the development of student's personality, mentality, social, responsibility, and skill. This program also presents religious meaning expected to be guidance in student's life.

d. Through the implementation of the Quran graduation ceremony as an evaluation to Islamic pre-school, in addition to many things contained in the implementation where involving a lot of people, resources and funding. This development program is interpreted as main activity in Islamic preschool Baitul Haadi. It aims is to improve the quality of religious education in the Islamic pre-school as well as a venue to interact among Islamic pre-school family, residents, administrators, parents, 
community, religious and community leaders and government.

e. Through the discipline of student learning process, starting from the application of discipline by leaders and teachers, administrators. Learning discipline development is interpreted as a significant asset of education that eventually returned to the interests of the students themselves. The main intention is to maintain the continuity and security or order of the educational process.

f. Through student orientation week in the early years of learning process arranged with planning, tasks division, development activities, monitoring and assessment related to such activities. This activity is done by all the members of Islamic preschool. This program enables to afford significant impact on the activities of the coming year and until they completed their education in Islamic pre-school. Student's orientation period is not only ta'aruf period in Islamic pre-school, but it is an introduction and practice period repeatedly until student's ability is increased.

These development activities are interpreted as an environment for moral management that students should be familiarized through student's activities. The goal is to realize expected vision and mission of Islamic pre-school.

Surveillance activities of Islamic preschool carried out by means of judicial and monitoring, direct assessments of ongoing student's activities and indirect student's written reports review, analysis oral reports, interviews with teachers and learners. Islamic pre-school head master supervises learning process and all teachers and student activities including Islamic pre-school student management. Teachers are given power to observe and direct their students. It means that Head master and teacher play significant role in attaining learning objective.
Besides surveillance, Islamic preschool provides services and assessment to the students. Such as awards and achievement reward. Teacher particularly assesses student activities in competition. Islamic pre-school management sets orphan and destitute students free from the school fee. The funding is allocated from Islamic pre-school mosque finance. Teachers also lead the student while having activities outside of the school provide the funding.

By learning and observing these findings, it is known that the management of Students in Islamic pre-school Baitul Haadi has been conducting a variety of activities, skills, and attitude and personality formation. In addition, Islamic pre-school also supervises students either in the class or outside the classroom, implementing discipline on every student's activity as well as conducting Islamic competition (Musabaqah) to stimulate student interest and ability of certain field of knowledge. This is accomplished continuously. Management activity such as planning preparation, student grouping, student development activities, supervision and observation and reward given to those who has high competence and interest will lead to the development of student quality and collaborate in achieving maximum learning objective effectively and efficiently.

Student management activities provide positive atmosphere such as (a) establishing student competence development to improve the quality of education, (b) establishing teacher's cooperation and responsibility in leading their students achieve expected competence. (c) Building close relationship among teachers, parents, administrators, and the society, (d) establishing high student and parent social attention through collaboration among learners, Islamic pre-school family, and the various elements of institutions as well as social-religious organization, (e) establishing the quality of it. 
Student management demonstrates that every effort lead to the real goal and dream. Parents will directly be able to observe their children development through their activities. Students are responsible to the tasks assigned to them. This situation stimulates student to compete, develop their talent, and build a good cooperation among Islamic pre-school family, parents, and society. Implementation of student management intends to increase learning quality through the implementation of management function supported by various activities and actions, experience and personality of the manager, the cooperation of all elements maintained continuously.

\section{Implication of Student Management toward Learning Quality Development}

From the conclusion, it is known that the quality of learning can be defined operationally as the intensity of systemic interrelated and teacher synergy, curriculum and learning materials, media, facilities, and learning systems in generating of process and objective optimally related to curriculum. Management of students applied in Islamic pre-school Baitul Haadi correlate for improving the quality of learning. This can be measured from the indicators of learning quality applied properly.
Learning is an aspect that plays an important role in the process of education management; education management is a significant aspect in reaching learning process in term of cognitive, affective and psychomotor. The quality of an educational institution is reflected in the quality of the learning process. Therefore, the criteria of quality and success of learning should be detail-organized, so it enables to be measured and observed.

Indicators of learning success can be observed from the learning process and purpose. It also can be measured from the level of learning achievement referring to the competence that characterizes the concept mastery observed and measured. Success is observed through learning process in general including stages of activities consisting the preliminary stage, the core activities, and closing activities.

Accurate management Implementation will improve the quality of learning in Islamic pre-school. Various activities and actions implemented in the school is supported by cooperation continuously. Its management implementation prioritizes implementation process and achievement of expected goals. The table below demonstrates the implications of implementation of student management in Islamic pre-school toward the development of learning quality.

Table 2. Management Activity, Management Activity Outcome and Learning Quality

\begin{tabular}{|c|c|c|}
\hline Management Activity & Management Activity Outcome & Learning Quality \\
\hline $\begin{array}{l}\text { Planning and student data } \\
\text { collection }\end{array}$ & Proper, scheduled, arrenged learning proces & $\begin{array}{l}\text { Able to lead Islamic Pre-school } \\
\text { students to the proper learning }\end{array}$ \\
\hline $\begin{array}{l}\text { Student placement into } \\
\text { various groups }\end{array}$ & $\begin{array}{l}\text { Scheduled and managed supervision of task } \\
\text { accomplishment, student involvement in } \\
\text { learning activity to create systematic process }\end{array}$ & $\begin{array}{l}\text { quality attitude in learning } \\
\text { process, student learning impact, } \\
\text { enhance student quality, } \\
\text { responsibility, competence, and }\end{array}$ \\
\hline $\begin{array}{l}\text { Conducting student } \\
\text { development }\end{array}$ & $\begin{array}{l}\text { Student development through various methods } \\
\text { and techniques }\end{array}$ & potential. \\
\hline $\begin{array}{l}\text { Student monitoring and } \\
\text { supervision }\end{array}$ & $\begin{array}{l}\text { Continuously involvement of student, staff, to } \\
\text { inherit discipline habit }\end{array}$ & \\
\hline
\end{tabular}


Achievement Obtained of Islamic pre-school Baitul Hadi Advanced Program in the Last 5 Years.

Table 3. Islamic Pre-School Baitul Hadi Student's Achievement Baitul Haadi 2005 - 2010

\begin{tabular}{|c|c|c|c|c|c|c|c|}
\hline No & Student's Name & $\begin{array}{c}\text { Area of } \\
\text { competition }\end{array}$ & Ranking & Level & Place & Year & Note \\
\hline 1. & Dea Riska & Tahfiz 1 Juz & III & National PTP & Medan & 2005 & \\
\hline 2. & Alkawira Nul Salam & $\begin{array}{l}\text { Tahfizh } 1 \text { Juz } \\
\text { Tartil }\end{array}$ & II & National & Medan & 2005 & \\
\hline 3. & Ilham Taufik & Tartil & II & National PTP & Medan & 2005 & \\
\hline 4. & Ilham Taufik & Tahfizh & I & Padang & Kec. P. Utara & 2005 & \\
\hline 5. & Ilham Taufik & Tartil & Harapan I & National & Aceh & 2006 & \\
\hline 6. & Merisa Angraini & Tahfizh & I & Padang & Kuranji & 2006 & \\
\hline 7. & M. Yusuf & Tahfizh & II & Subdistrict & P.Selatan & 2006 & \\
\hline 8. & Dea Riska & $\begin{array}{l}\text { Tahfizh } 1 \text { Juz } \\
\text { Tilawah }\end{array}$ & I & West Sumatera & Pariaman & 2006 & \\
\hline 9. & Sri Yulia Esti & $\begin{array}{l}\text { Tahfizh } 1 \text { Juz } \\
\text { Tilawah }\end{array}$ & I & district & $\begin{array}{l}\text { Solok } \\
\text { Selatan }\end{array}$ & 2007 & \\
\hline 10. & Sri Yulia Esti & $\begin{array}{l}\text { Tahfizh } 1 \text { Juz } \\
\text { Tilawah }\end{array}$ & II & Padang & Padang Utara & 2007 & \\
\hline 11. & Suriani Putri & Tahfiz 1 Juz & I & Padang & K.Tengah & 2007 & \\
\hline 12. & Ilham Taufik & Tartil & I & Padang & Purus & 2008 & \\
\hline 13. & Suriani Putri & Tahfizh & I & West Sumatera & Pasaman & 2009 & \\
\hline 14. & Yola Oktavia & Tahfizh & I & Subdistrict & P.Selatan & 2010 & \\
\hline 15. & Muhkdil Khairi Idris & Tahfizh & I & Subdistrict & Lubeg & 2010 & \\
\hline 16. & Ifkar Rasyid & Tahfizh & II & Subdistrict & K.Tengah & 2010 & \\
\hline 17. & Mardhatillah Aflyandri & $\begin{array}{l}\text { Tahfizh } 1 \text { Juz } \\
\text { Tilawah }\end{array}$ & II & Subdistrict & P. Barat & 2010 & \\
\hline
\end{tabular}

Learning quality and achievements obtained is influenced by various factors; those factors are learner factors, infrastructure factors, tool, media, facility factors, environmental factors, process and objective factors, as well as parent's factors. It is identified from research findings. Management applied demonstrates the increasing of learning quality that is maintained student's capacity and ability. Islamic pre-school obtains the best achievement in the Padang and becomes model of the schools.

Based on the findings, it is recognized that Islamic pre-school Baitul Haadi leads to the formation of successful and qualified students. It is measured management activities organized by school principals through various method and techniques. Such management is able to achieve maximum, effectively and efficiently learning objective.
This is appropriate with Islamic pre-school implementation guidelines which regulate admission of learners, set of guidance, monitoring, and conducting evaluations (Depag, 2005).

In addition, Arni \& Hadianto (2000) explains that the management of learners is the process of setting activity relating to student learning process to achieve educational goals. Student Management refers to the recording of admissions process until the students complete his study or graduate from education institution.

The whole educational program in Islamic pre-school is intended to develop students' self-development, attitude and skills. Students in an educational institution are basically an input that will be managed to be expected output. Management and quality determine the objective of a process. 
Suryosubroto (2004) stated that student management refers to the recording of admissions process until the students complete his study or graduate from education institution. Syafaruddin (2005) also stated that student management includes admissions process, placement and student development. While Arni \& Hadiyanto (2000) argues there are five kinds of activities in students' management. Imron stated that there are 13 activities in learner management (in elementary school). Besides Nawawi (1982) revealed that headmaster has the functions and role in student affairs which regulates the admission of learners, guidance and counseling, attendance record, organizes cocurricular programs, and organizes the transferring of new students.

Student management performed by headmaster initiated from student's registration through regular administration, implementing various regulations related to educational success with programmed development, has realization the implementation of regular education according to the desired expectations. Organizing the students to several sections associated with each task and empowering all learners in various forms has been realizing the organization that is composed and transparency at every grade level and their respective groups. This increases the systematic learning process to build qualified, discipline and responsible students. It realized the objective of development program based on student's group. It also established Islamic atmosphere, systematic learning, qualified and discipline student, and responsible student. Besides, it built a good cooperation with parents, parents' expectations fulfillment, learning discipline culture, student talents stimulation, and the Quran understanding competition development.

Student supervision is conducted by empowering all staff, evaluating and monitoring continuously, sharing and reminding. Besides, it also attains through (uswatun hasanah) expected model approach, resolute, patient, raises sense of responsibility to carry out the task. Its staff provides students to evaluate and measure student development in attaining learning objective as well as preparing qualified students in every field of knowledge.

This student management applied by head master of Islamic pre-school Baitul Haadi enhances student capacity and ability. These students are the qualified student in both quantity and quality. Quantitatively, student's success can be measured from their understanding, through oral and written evaluation. But the main focus is in the term of student behaviour and morality in everyday life as Islamic pre-school educational mission.

Religious Education is to realize Islamic education which is education quality as its priority. This aims can be attained through uswatun hasanah approach, skilled in worship and able to apply it in everyday life, and to realize student's good behavior education. This mission is in accordance with education objective of Islamic pre-school. "The mission is to provide basic skills for society to develop their life as a Muslim, pious and good behavior and glorious. This is in accordance with what is stated in Indonesian government regulation number 55 of 2007, that the function of religious education is to prepare students to be part of society members who understand and practice the values of its religious teachings (Depag, 2005). Madrasah diniyah awaliyah (Takmiliyah) supports and helps student's Islamic education understanding obtained in Elementary School in order to increase students' faith and piety to Allah.

Islamic pre-school Baitul Haadi management is in accordance with statement of Syafaruddin (2005), that the student development as part of student management associated with the preparation of qualified graduates in every Madrasah, or school with the involvement of staff, teachers, and employees and society. Islamic pre-school needs to build up coordination, cooperation through the coordination meeting, cooperation, and communication through; 
periodically coordination meeting and program evaluation meeting in every end of the year.

This Management applies management functions and has a significant potential both institutional potential and potential of Human Resources (HR) in implementing Islamic religious education, maintain and improve the quality of it School. This management function leads the realization of qualified and successful students, disciplined and responsible, as well as good behavior; it has been implemented in coordinated, structured and programmed. Management of learners performed determined the student's success to the expected goals as contained in the vision and mission, objectives, and school program. The accomplishment of this program is built up continuously from a good coordination among school principal, teachers, learners, parents, administrators and community, as well as the government. This cooperation enables Islamic pre-school Baitul Haadi to improve the quality of its school resources and becoming the best and popular among other Islamic preschool in Padang City. Islamic pre-school Baitul Haadi is able to empower teachers and learners, society through variety of educational activities and social events.

Islamic pre-school student management is supported by five essential elements; qualified teachers, student's disciplined quality and personality as reliable human resources, implementation of systematic and programmed curriculum, coordinated, practical, systemic, and good financial management. Then, it is also supported by adequate infrastructure to sustain the education process well, in addition to other management. Implementation of this culture has always maintained and improved continuously through the development and improvement of the school human resourcee (school principal, teachers, students, and administration) and by building up good relations with the board, parents of students, government agencies, professional organizations, social religious organization, and community leaders and religious leaders.

According to the social order, the head master of Islamic pre-school has sought and worked to meet the demands of leadership and the duty given to him. Management as the executive of activity and social society strive for Islamic values implementation. Thus, the principle of cooperation and responsibility is inherent in Islamic managerial concept. Islamic pre-school head master has implemented various Islamic principles in managing the organization for the progress of humanity. In Islam, there are some interesting things to be understood; that God has various greatest reliable and extraordinary competences. The presences of God's attributes are reflected through His beautiful names (Asmaul-Husna).

Alquran (Al-Baqarah, 2: 255) has convincingly determined Allah as the greatest and most reliable manager and administrator. In addition to a strong argument of the existence of management concept, there is also a command to carry out management functions as well as possible. The Quran wrote about the necessity to recognize Allah's attributes indicate the need to carry out the functions of management as exemplified by Allah. (Nata, 2005). Management skills need to be developed with professionalism, credibility and leadership ethics to be effective in managing an educational institution. The duties of Baitul Haadi head master are very relevant and appropriate both internal and external, as stated by Riva'i (2009) as follow:

\section{Internal Duties}

a. Write daily plans, weekly, monthly, semiannual, and annual

b. Nurturing and guiding each staff in their respective fields (manager) 
c. nurturing and monitoring the financial administration and supplies administration

d. Fostering the achievement of good teaching situations (administrator).

e. lead school ceremonies (leader),

f. to organize, develop, utilize, existing facilities for the achievement of desired objectives of the organization (manager),

\section{External Duties}

a. Organize a meeting with parents of learners (leader),

b. Organize working network with local government in school development.

c. Build up relationship with social agencies that can assist in the implementation of school curriculum (manager),

d. establish relationships with private institution in order to attempt the improvement of education and teaching in schools (manager),

e. Build up cooperation with educational institutions vertically or horizontally in the promotion and development of education in schools (manager).

Management applied to students of Islamic pre-school is successful with high quality obtained. Management applied implicates on learning quality improvement. There are influenced factors applied properly. Learning quality is improved through the implementation of student management applied by Islamic pre-school head master. It enables to set students to have superior performance and learning impact. Indicators of this learning quality measure from learning system in organizing the process and learning objective optimally in accordance with the demands of curriculum. It is shown from various student activities. Baitul Haadi learning system applies group and individual a classical system using various methods and approaches, programmed, structured and systematic strategies. Thus learning system generates appropriate process and learning outcomes. This is shown from the establishment of student quality, virtuous students, disciplined and responsible (having properties commendable), as well as master the competencies and qualified.

Djamas (2005), suggests that the headmaster is a central figure that determines the center point and rhythm of a madrasah. Headmaster has a strategic role, as it has a central power as activator of Islamic preschool, as well as the one who understand the duties and functions and have concern for Islamic family. Mulyasa (2004) stated that the success of Madrasah-based management is totally influenced by various factors, both internal and external factors. Generally, it includes education quality improvement organized by goverment, socialization of education quality improvement, mutual cooperation and kinship, human resources potency, formal and non-formal organization, professional organizations, as well as the support of business and industry.

In education context, the sense of quality includes input, process and output of education. Educational input is everything that should be available as needed for the process. The process of education is changing something into something else. Output of education is the school performance including school achievement resulting from the process and school behavior (Rivai \& Murni, 2009). School educational input is resources, software, as well as expectations to the process of education. Human resource inputs of Baitul Haadi comprised of the Head master, deputy, teachers, administration staff, and resources such as equipment, supplies, and materials that are necessary for the educational process. While abstract input is school's organizational structure, regulation of teachers and learners, teachers' and learners' task, plans and education programs.

Educational process in Baitul Haadi is the process of decision-making, the process of organization management, program management process, the learning process and the process of monitoring and evaluation. This educational process is excellent and high 
quality because of the coordination and harmonization and integration of Islamic preschool inputs done properly and wisely. Therefore, it enables to provide proper learning atmosphere, able to motivate student's interests and empower students into learning activities. Students are hoped to be able to maintain self-development. This process significantly determines educational outputs. Achievements resulting from the process or Islamic pre-school behavior can be measured by its quality, effectiveness, productivity, efficiency, innovation of working quality, and the school moral. V output quality can be recognized from school final exam, academic competition, such as annual events in Islamic New Year festivals. While non-academic achievements is such as piety, honesty, decency, discipline and other extra-curricular activities. Achievements resulting from the process of school behavior both in quantity and in quality can be supervised proudly by parents. Succeed in competition, such as superior in an activity, qualified and courteous in attitude, and build up a good relationship.

The quality of religious education cannot be measured with statistical tables. But it is possible to be measured by the totality of students as a person and a part of social system. Therefore quality and achievement of religious education should be oriented to the following matters:

a. Personal quality target achievement, both as religious or nation person.

b. Integration of religious education with overall process as well as other educational institution.

c. the achievement of internalization values and norms of religious functions morally to develop the entire social and cultural system

d. personal attentiveness of future demands, social and cultural ongoing transformation.

e. Formation of insight, intelligent, rational, besides active learning activity.
According to Reynolds (1997),
Madrasah Based Management (MBM) depends upon the ability of head master to organize the elements of success: (1) utilize wide system perspective, (2) understanding the context of changes, (3) develop perspective of leadership and expertise, (4) creating vision, (5) develop strategic planning skills, (6) describes new roles, (7) improving work environment, (8) understand the dynamics of group, (9) describes accountability.

Madrasah based management (MBM) which is decorated in the form of communitybased management by the Ministry of Religion is expected to improve efficiency, participation, quality, and responsible to the public and the government. According to Mulyasa (2004), MBM can be recognized from how the Madrasah optimize its performance, learning process, teaching resources management, professionalism of the staff, and administrative system. Syafaruddin (2005), states that only by readiness of effective educational management, Islamic educational institutions can respond the changes so it will not stagnate and left behind in the rapidly changing dynamics.

\section{CONCLUSION AND RECOMMENDATION}

Students' management applied in Islamic pre-school through the management functions is able to provide the successful of student's education and learning implementation. The implications of management applied have meanings and major influences on improving learning quality, both in the learning process as well as on results and objectives. Students' management applied in the school through various management activities are preparing pious students, being a good attitude and behavior student, success and quality, qualified, and able to understand and master the learning competencies. 
Student management applied in Islamic pre-school is planning activities of students' admission process through the administration regularly with various regulations related to the success of education. It is also completed through students organizing to some parts associated with each task that is wellorganized, orderly and structured, and empowers all students in duties and activities. The implementation of education is organized according to the desired expectations. Students' supervision conducted by empowering all staff, evaluating and monitoring continuously, in many ways, providing services to learners, evaluate activities to be responded by various motivation to stimulate the achievement of expected goals. This activity guides to raise qualified learners, disciplined and responsible, as well as good behave, train high sense of responsibility, and train students' competitive skill.

Implications of Islamic pre-school management implementation provide meaning and effect to improve the quality of students learning, in learning process as well as the results and objectives. The quality of learning process leads students to the behavior and impact of excellent learning, learning atmosphere supports active learning process, innovative, creative and fun, quality of results and expected goals, realize the quality of learners; pious students, disciplined and responsible, learning competencies and achievement.

Islamic pre-school became the center of education for children school age basic level education in the field of Islamic religious education. As a sub-system of Islamic education, its presence strongly supports national education goals, particularly in the conception of human faith and fear of God Almighty. Student Management applied in Baitul Haadi already participated actively in developing the ability and character as well as human civilization. The aim is to develop the potential of students to be pious person, noble, healthy, knowledgeable, capable creative, independent, and become democratic and responsible citizen. Specifically, its aim is to realize the quality of Islamic education based on the Quran and al-Hadits.

Elements concerned must always develop its performance, especially school principal and teachers directly involved in education process. Student management applied and developed in Islamic pre-school needs to be maintained and further enhanced. The obstacles need to be resolved. Especially to improve religious teacher competence through professionalization of curriculum training and other supporting sciences.

To the elements involved in the management of education in the Islamic preschool is expected to give full support, particularly for education process in Islamic pre-school. It also expected to the mosque administrators, parents of students and society, local government, the head office of Religion Ministry, manager/staff of FKMD institution. As a component of national education system, Islamic religious education needs to be facilitated to flourish, nurtured and developed by all components of the nation, including the government and local governments.

The Ministry of Religious Affairs as a technical adviser is expected to provide and implement the guidance and constant supervision in accordance with applicable regulations. Islamic pre-school management is as an important part of Education General Dipartment of Early Chilhood Islamic Education (Diniyah) and boarding school. It maintains religious values as a moral foundation in spiritual life of society, nation and state with the mission of improving the quality of religious education and empowers religious institutions. To Padang Local Government, it is expected to provide educational resources to support religious education. Islamic Pre-School as stated in the Regulation no. 55 of 2007 section 12 and 25. The Islamic religious education through Islamic Pre-School is implemented in order to support long life education and Regulation no. 6, 2003 and Governor Decree no 70 in 2010. 
To organizations FKMD / KKMD, It is expected to actualize the role of Islamic pre-school education to be more empowered and succeed, because FKMD is indispensable in organizing all potencies of Madrasah diniyah or Islamic pre-school (Decree of the religion Minister Affairs no.3, 2006, on the organizational structure and Religion ministry Management). To the observer of religious education, it is expected to do further research on the focus issues.

\section{REFERENCES}

Arikunto, S. (2010). Edisi Revisi: Manajeman Penelitian. Jakarta: PT. Rineka Cipta.

Arni, M., \& Hadiyanto, R. (2000). Supervisi Pendidikan. Fakultas Ilmu Pendidikan UNP.

Azizy, A. Q. A. (2003). Pendidikan agama untuk membangun etika sosial: mendidik anak sukses masa depan: pandai dan bermanfaat. Aneka Ilmu.

Depag, R. I. (2005). Pedoman Manajemen Berbasis Madrasah. Jakarta: Dirjen Kelembagaan Agama Islam.

Djamas, N. (2005). Manajemen Madrasah Mandiri. Jakarta: Puslitbang Pendidikan Agama dan Keagamaan.

Lincoln, Y. S., \& Guba, E. G. (1985). Naturalistic inquiry (Vol. 75). Sage.

Mubarok, A. (2000). Jiwa dalam al-Qur'an. Jakarta: Paramadina.

Muhadjir, N., \& others. (1996). Metodologi penelitian kualitatif. Yogyakarta: Rake Sarasin.
Mulyasa, E. (2004). Pedoman Manajemen Berbasis Madrasah. Departemen Agama RI.

Mustafa, H. A., \& Aly, A. (1999). Sejarah pendidikan Islam di Indonesia: untuk Fakultas Tarbiyah, komponen MKDK. Pustaka Setia.

Nasution, S. (1992). Teknik Penelitian Naturalistik Kualitatif. Bandung: Remaja Rosdakarya.

Nata, A. (2005). Pendidikan dalam perspektif al-Qur'an. Jakarta: UIN Jakarta Press.

Nawawi, H. (1982). Organisasi sekolah dan pengelolaan kelas sebagai lembaga pendidikan. Gunung Agung.

Rahiem, H., \& Mochtar, E. (2001). Arah Baru Pendidikan Islam di Indonesia. Logos Wacana Ilmu.

Reynolds, L. J. (1997). Successful site-based management: A practical guide. ERIC.

Rivai, V. H., \& Murni, S. (2009). Education Management. Analysis Theory and Practice. Jakarta: Rajawali Pers.

Safwan, M., \& Kutoyo, S. (1980). Sejarah Pendidikan Daerah Sumatera Barat. Padang: Depdikbud Proyek Inventarisasi dan Dokumentasi Kebudayaan Daerah.

Suryosubroto, B. (2004). Manajemen pendidikan di sekolah. Rineka Cipta.

Syafaruddin, N. I. (2005). Manajemen Pembelajaran. Quantum Teaching: Jakarta. 